\title{
THE IMPLEMENTATION OF USSR (UNINTERRUPTED SUSTAINED SILENT READING) ON STUDENTS' READING MOTIVATION AT
} ANANDA ISLAMIC SCHOOL

\author{
Muhammad Abduh Al-Manar \\ University of MuhammadiyahTangerang \\ E-mail: abduh.almanar33@gmail.com
}

\begin{abstract}
The present study will investigate the effect of implementing USSR (Uninterrupted Sustained Silent Reading) program at national plus school Ananda Islamic School. Iinterview and field observation was designed for data collection. To succeed the program, the students freely choose the storybook they like and they would be given special time at school to read during the program. The teacher will show a role model and a value of reading by joining the program of reading books with a pleasant, relaxed atmosphere and lack of pressure. This study will use an observation log, questionnaire surveys, and semi-structured interviews. 20 students were observed during USSR program within 4 weeks including a survey and 5 students will be taken as a sample through purposive sampling method.
\end{abstract}

Keywords: EFL Learning, Uninterrupted Sustained Silent Reading (USSR), Reading achievement, Reading Comprehension 


\section{INTRODUCTION}

When we talk about reading motivations we refer to (1) interest, (2) dedication, and (3) confidence Jenna 2010. The needs of the students to read at the moment are urgently needed as the students' performance on reading is getting down. Improving students' interest and confidence through reading are like improving their competence by building new habits to them. The students desire to read is drastically low and the students' motivation of reading are getting worse and worse. As a result, the students nowadays refer to have visual information rather than reading a paragraph or text. Reading is like an open window for the students to get knowledge and to be able to comprehend and understand a lesson, reading competence of the student is becoming a major concern of the basic reading skill. The researcher also believes that good motivation in reading since early childhood will bring the students to become successful student in the future.

Urgency of students' reading motivation

A good student's ability and motivation in reading will perform better reading comprehension of the students. The future success of all students hinges upon their ability to become proficient readers (Moats, 1999). Making a reading program as a habit will provide opportunities for children to develop cognitively and linguistically. Oldfather (2002) states that students tend to avoid reading when they dislike texts. Besides, texts and topics that are not connected to students' background knowledge or context result in their losing interest to them. By having intensive reading program in USSR, reading will enable the students to acquire knowledge and skill to learn individually as an autonomous learner. It also will improve their quality of reading in their daily habit. As noted by Gambrell (1978), "SSR can be the component of the reading program which gives pupils the opportunity to transfer and apply isolated skills in a pleasurable, independent experience."

Today's educators need to recognize the important of the students' reading awareness are getting low. As a result, technology and gadget almost take place of the use of book. Therefore, a major concern in developing students cognitive by improving the students' reading motivation through USSR program is the basic concern of this paper. Bisset (1969) found a significant increase in the amount of student reading when students had access to a variety of reading materials in the classroom and USSR will help the

The Implementation of USSR (Uninterrupted Sustained Silent Reading) on Students' Reading Motivation at Ananda Islamic School Al-Manar 
students to provide an opportunity to read in sustain and silent reading program. This research is hoped to be beneficial to the students' performances.

\section{THEORITICAL REVIEW}

The importance of the program USSR (Uninterrupted Sustained Silent Reading) is a program proposed by the researcher to improve the students' motivation in reading. It was first introduced by Moore, Jones, and Miller in 1980. This program was first implemented to foster students' positive attitudes towards reading as well as improving the reading achievement. Students reading' behavior will automatically improve students' reading achievement and students' reading achievement will also give significant impact to the students' cognitive skill. The program of USSR come with an expectation by providing students regular schedule to have a chance to read silently and sustained. It is also stated in the seminal article by McCracken (1971) set the main framework that the objective of USSR, or any of the variant names it is known by, is to develop each student's ability to read silently without interruption for a period of time (McCracken, 1971).

It is also mentioned in the public journal from Nanyang Technological University by Anthony Seow on "What Do We Want out of USSR?" that USSR is part of the school Extensive Reading programme (ERP) to help pupils form good reading habits for extensive reading and also desire to read on their own during their free time.

\section{METHODOLOGY}

The student of five graders elementary school Ananda Islamic School will be the subject of this study. The students are mostly coming from different background of English competency and cognitive skill. The students will regularly read the books they chose at first and will start the program fifteen minutes before the learning and teaching starts. The number of the population will be twenty students.

During the program, the teacher will join the activity and watch the students enjoying the program. The purposive sampling technique, also called judgment sampling, is the deliberate choice of a participant due to the qualities the participant possesses Sulaiman (2016). This research will use purposive sampling that five participants will be taken as the sample of this research. These are the criterions of the researcher for the selected participant:

a. The participants that are actively and intensively join the program regularly with no absentee of the programs

Globish, Vol. 7, No. 1, July 2018, 36-43 
b. The students that has reading difficulty understanding the meaning and ideas of the book.

c. The students have great reading log record from each days as the students reading progress

Case study method enables a researcher to closely examine the data within a specific context. In most cases, a case study method selects a small geographical area or a very limited number of individuals as the subjects of study Zaidah (2007).

This research will use a case study as the design of this research and it will focus on the students' responses and experiences during the program of USSR. It is conducted to have better result on the students' responses to the programs of USSR. Investigations of the program is conducted to get the data from the students' responses. Therefore, the research findings and participants' responses and result from the programs would be transcribed that would be interpreted into descriptive forms.

This research involves the participants of the selected students who joined the programs so that the data gathered would objectively describe the result of the programs. There are some steps to conduct this study:

1. The researcher tries to conduct an open-ended question to the participants at the first phase to get more detail information related to the students' reading comprehension.

2. The researcher took a field note and did an observation during the reading program USSR Uninterrupted Sustained Silent Reading.

3. Interview is conducted to get to know the students' responses about their experiences to the program.

4. Result of the interview and observations will be analyzed, reviewed, coded, synthesized, categorized and interpreted in complete form.

5. Finally, the data gathered will be formulated into a complete conclusion and suggestion.

\section{FINDING AND DISCUSSION}

USSR will be a part of the teacher learning objectives and an intensive program on the students reading motivation. The data collected and described in the findings show how effectiveness of the program to the students' reading motivation. By interviewing the students and describing the students' responses in narrated, the researcher found huge positive impact to the students reading motivation and also their cognitive progress to The Implementation of USSR (Uninterrupted Sustained Silent Reading) on Students' Reading Motivation at Ananda Islamic School 
others lesson. The researcher daily observation and field note also described clear improvement toward the students' attitude to their enthusiasm in reading.

\section{Student 1}

"What I like about the program is that we could choose the story we like to read and it is exciting to have time to read at school that I rarely read book at home" The statement above shows us that the students are happy to read by freely choosing the book they like to read and the program also unintentionally asking the student to be familiar to the students to read.

\section{Student 2}

“For the first time, I thought it was a boring. I don't really like reading, I prefer to watch like a movie, film and etc, but because it is a program from school I felt my own excitement during reading." I could spend many minutes after a few days joining this program. I thought I never like reading, but this program makes me like to read. I sometimes continue reading in leasure time at home. Now, I understand why a few people could spend many hours reading because when we found the joy of reading, we will forget the time and keep on reading."

The researcher captured from the students 2 opinion that at first, she is not into reading, but the program helps her to be accustomed to reading as before she did not like it. She develops new habit that is reading.

\section{Student 3}

"My reading was really bad, I sometimes took many minutes to understands sentences, main idea, and also a story, but this program improve my reading comprehension. I can easily understand the story from the paragraph that I read because now I get used to it now."

The previous response from the student show that the program helps the students to understand a text by joining the program and it also gives a proves that the student can acquire a new skill independently.

\section{Student 4}

"My reading habit is not as good as my friends. I usually read some books if it is interested for me to read. This program allows me to bring and choose the book that I like to read

Globish, Vol. 7, No. 1, July 2018, 36-43 
freely. It is like building a new habit fro me. Now, I never forget to bring my storybooks to the school. By the time, I start enjoying reading a book."

\section{Student 5}

"My reading skill has improved. It happens sometimes when I read some definitions or meaning from the textbooks of the lessons I can understand the ideas and what the passage and text mean very fast. Unlike before, I also sometimes continue the pages I read at school to be read at home." 


\section{CONCLUSION}

Based on the interviews and students responses through field-note and observations during the research, USSR (Uninterrupted Sustain Silent Reading) gives significant effect to the students especially in their reading interest. It is found from their responses through interview that there are 3 aspects and changes that the students mostly experience from the program.

Firstly, they experienced the joy of reading by the program of USSR. They used to feel boring when reading but now they do not. Secondly, the students are getting use to understand the text or passage in English easily. They can comprehend and get the meaning of the text faster than before. This helps the student to improve their performance in their cognitive skills at class. Thirdly, Building new habit and routine are successfully happened. The students right now feel the excitement of reading without any pressure from the teacher's instruction. From the five samples taken of the twenty populations, the five samples show significant effect to their reading motivation and cognitive performance. Those five samples showed that USSR had improved their reading motivation and it also gave clear statement that USSR is recommended to be a part of the school daily program to improve students' reading awareness and motivation.

Globish, Vol. 7, No. 1, July 2018, 36-43 


\section{REFERENCES}

Bisset, Donald J. "The Amount and Effect of Recreational Reading in Selected Fifth Grade Classes." Doctoral Dissertation, Syracuse Univ., Syracuse, NY, 1969.

Gambrell, L.B. (1978). Getting Started with Sustained Silent Reading and Keeping it Going. The Reading Teacher, 32:3, pp. 328-331.

Hunt, L.C. "The Real Task of the Reading Teacher." Burlington, VT: University of Vermont Press, 1972.

Jenna C, John T. (2010). Motivating and Engaging Students in Reading. The Nera Journal. Vol. 46 (1). University of Maryland, Maryland.

Liker E, Sulaiman A, Rukaya S (2016) Comparison of Convenience Smapling and Purposive Sampling. American Journal of Theoretical and Applied Statistics. Vol. 5, No. 1, 2016, pp. 104. Doi: 10.11648/j.atjtas.20160501.11

Moats L.C (1999). Teaching Reading is Rocket Science: What expert teachers of reading should know and be able to do. Retrieved from http://www.ade.state.az.us/azreads/reading1st/Resources/006.pdf

Oldfather, P. (2002). Students' experiences when not initially motivated for literacy learning. Reading and Writing Quarterly, 18, 231-256.

Zaidah Z (2007) Case Study as a Research Method. Jurnal Kemanusiaan bil.9, Jun. university Technology Malaysia

The Implementation of USSR (Uninterrupted Sustained Silent Reading) on Students' Reading Motivation at Ananda Islamic School 